\title{
Chapter 6 \\ (Post)graduate Education Markets and the Formation of Mobile Transnational Economic Elites
}

\author{
Sarah Hall
}

This chapter is set within the resurgence of interest in economic elites across the social sciences (see, for example, Daloz, 2010; Savage \& Williams, 2008). Clearly understanding the activity of economic elites, including those who work in the financial services focused on in this chapter, is not an entirely new endeavor within economic geography and the broader social sciences (see, for example, McDowell, 1997; Thrift, 1994). Building on this work, however, the recent and growing interest in elites marks the development of a more sustained academic engagement aimed at understanding not only the background of elites but also the nature of their work and its significant implications for the global economy. Beyond the academy, this developing interest in elites has received considerable impetus from the 2007 to 2008 financial crisis and the ensuing recession because of how the elites' working practices, particularly those undertaken by investment bankers in financial services in the area of securitization (the process of transforming an illiquid asset into a security), which are argued to have been central to both causing the crisis and contributing to its geographically disparate consequences (Tett, 2009).

Inspired by this growing interest in elites and their working practices, I focus in this chapter on the role of postgraduate education in facilitating entry into-and upward career progression within-early-career labor markets in investment banking in London's international financial district. I take as my starting point the considerable attention that has been paid to the role of educational background in elite formation, led by the work of Bourdieu (1989/1996). The development of this work, particularly in the sociology of education, has documented how individuals strategically accumulate credentials in order to secure positional advantage vis-à-vis other job seekers in their chosen labor market (see, in particular, Brown \& Hesketh, 2004). I develop this literature by examining how education beyond the first degree

\footnotetext{
S. Hall $(\varangle)$

School of Geography, University of Nottingham,

Sir Clive Granger Building, Nottingham NG7 2RD, UK

e-mail: sarah.hall@nottingham.ac.uk
} 
level (i.e., beyond bachelor's degree) represents an important means by which earlycareer financial elites are inculcated into the meanings and competencies associated with normalized, legitimated business practices in London and into the corporate culture of their employing firm.

I suggest that these forms of education, alongside the more widely studied forms of educational background, have important implications for both the spatial and social mobility of financial elites. My approach advances understandings of the spatial mobility (or otherwise) of financial elites. In this respect work on elites has more generally often labeled them as, for example, a transnational capitalist class (Sklair, 2001) or global elites (Castells, 1996). These labels, and the discourses that surround them, suggest a highly mobile group of topologically linked individuals who are only loosely embedded in topographical space while being situated within particular geographical locations, cities, or regions. However, by focusing on the role of education in elite formation, I suggest that elites combine elements of both topological mobility and connectedness with topographical specificity because their working practices and careers are shaped in part by the still largely national educational systems in which they are produced and the distinctive working cultures associated with different, place-based economies - the international financial centers in the case of the financial elites I study here. Meanwhile, I suggest that socially the case of finance demonstrates how many of the networks created through postgraduate education continued to be structured along social lines. In particular, mobility into and within elite financial labor markets remains comparatively limited to an educational and occupational elite, in spite of the widely held view that the growing importance of postgraduate education signaled the rise of a more meritocratic global economy - and City of London in particular - where individuals can succeed if they invest appropriately in their human capital (Becker, 1994). Taken together, I therefore argue that postgraduate education is an important but hitherto comparatively overlooked element in creating financial elites who combine elements of topological financial networks inseparable from the topographical dimensions of socioeconomic practice in financial services.

I develop these arguments over four further sections. In the next section, I examine how work on the role of educational background, particularly in the sociology of education, can be developed to provide a fuller understanding of the role of ongoing education in shaping socioeconomic practice within elite labor markets. I then introduce the different elements of the postgraduate landscape as they pertain to financial elites working in investment banking in the City of London. In the final substantive section of the chapter, I consider the spatial implications of this ongoing education for a group of early-career financial elites employed by investment banks often assumed to be unproblematically transnational and highly geographically mobile. I conclude by reflecting on the implications of this argument for work on the geographies of elites more generally and on their spatial and social (im) mobility. 


\section{Financial Elites, Education, and Socioeconomic Practice in the City}

As noted in the introduction, the relationship between educational background and entry into elite networks has been extensively studied, led by the work of Pierre Bourdieu (1980/1990, 1989/1996). A central component of this research is Bourdieu's identification of three interrelated forms of capital (economic, social, and cultural) that form an individual's habitus (Bourdieu, 1980/1990). Work in the sociology of education has focused particularly on institutional capital, arguing that it is gained through the acquisition of education credentials, as well as through membership in other formal groups (see, for example, Waters, 2007). However, although Bourdieu only discusses education explicitly in relation to institutional capital, research, particularly in the sociology of education, has revealed how education also plays an important role in the acquisition of the other forms of cultural and embodied capital as individuals learn accepted ways of being and doing through their educational experiences (Brown, 2000; Brown \& Hesketh, 2004; Waters, 2009).

This emphasis on the ways in which institutional, cultural, and embodied capital is acquired through education has been particularly evident regarding the relationship between education and the financial elites focused on in this chapter. Most notably, in the case of the City of London educational credentials from a small number of fee-paying public schools and elite universities, the University of Oxford and Cambridge in particular, have been identified as key determinants of successful entry into London's financial labor markets prior to the deregulatory changes of Big Bang in 1986, (Kynaston, 2002; McDowell, 1997). Educational credentials obtained from these institutions acted as a form of institutionalized cultural capital by indicating the possession of the objectified and embodied forms of cultural capital associated with "gentlemanly" capitalism (Augar, 2001). Indeed, as Thrift (1994, p. 342) has argued, gentlemanly capitalism was based "on values of honor, integrity, courtesy and so on, and manifested in ideas of how to act, ways to talk [and] suitable clothing" (see also Tickell, 1996). These embodied forms of working in the City have been argued to have had important implications for how the City was regulated by dense social networks based on shared educational backgrounds, through which trust based relationships could be formed (Pryke, 1991). More recent work has revealed how newer forms of educational credentials continue to reproduce the importance of the relationship between the educational background-based entry into financial elite labor markets and the embodied, institutional, and cultural capital needed to work successfully in these environments. For example, Masters of Business Administration (MBA) alumni networks from leading business schools have been shown to be an important way of securing upward career progression within investment banks, especially those headquartered in the United States where the MBA is more fully integrated into investment banking career pathways (Hall, 2008).

However, despite the acknowledged importance of educational background in securing entry into these elite labor markets, it is important not to paint a naively 
simple picture in which obtaining credentials from elite educational institutions was the only way of entering financial services work in the City of London. Such caution is particularly important given the marked changes in the nature of elite financial labor markets and work in the City of London that have occurred since much of the literature on "gentlemanly capitalism" was written in the 1980s and 1990s. Of particular importance for my focus on investment banking labor markets in this chapter are the changes associated with financial services work during the period of rapidfinance-led growth and innovation in the 2000s (Engelen, Konings, \& Fernandez, 2010; Froud, Johal, Leaver, \& Williams, 2006). Alongside the growth of new financial products, particularly securitization requiring greater technical competency and quantitative skills, this period saw elite financial labor markets in London expand beyond employment in merchant and investment banks to include new forms of financial intermediation offered by actors including private equity firms, hedge funds, and sovereign wealth funds (Folkman, Froud, Johal, \& Williams, 2007; Wójcik, 2011). The related diversification and growth in elite financial labor meant that the old-school-network forms of recruitment based on educational background could no longer provide the number of elites demanded by financial labor markets (Leyshon \& Thrift, 1997), suggesting changes in the relationship between education and elite financial work. In particular, these developments indicate that research needs to focus not only on the relationship between educational background and financial elites, but also on the ways in which education, including that undertaken after a first undergraduate degree, was important in securing entry into elite financial labor markets and inculcating individuals into the required skills, competencies, and new forms of embodied and cultural capital demanded by the changing nature of the City of London. These concerns form the basis of the rest of this chapter, in which I draw on the case of early-career investment bankers in examining the intersection between postgraduate education and everyday socioeconomic practice in the City in order to better understand the role of education in inculcating elites into particular working environments and its geographical implications for those persons often assumed to be globally mobile financial elites.

\section{Postgraduate Education and Legitimate Elite Financial Practice}

To address these concerns, I turn to a set of arguments made by Bourdieu (1980/1990, 1989/1996) concerning everyday socioeconomic practice, to his work on doxa-an idea still not widely developed in relation to education (although, see also Faulconbridge \& Hall, 2014). In so doing, my analysis draws on the wider interest in normalized practice within socioeconomic life as it relates to processes of learning and the reproduction of practices in geographically specific ways (Amin \& Cohendet, 2004; Wenger, 1998). For Bourdieu, assumptions and understandings about appropriate everyday practice in any given context, or doxa, strongly influence an individual's actions and thoughts. This insight is important for the arguments in this chapter for two main reasons. First, the concept of doxa suggests that 
the everyday socioeconomic practices of financial elites need to be understood in relation to the geographically specific understandings of what constitutes legitimate behavior in any given spatially situated economy. This raises significant questions about the role of education in reproducing these understandings because its part in inculcating early-career elites into the accepted and legitimated forms of action within - as regards this chapter-the City of London. Second, and following on, Bourdieu highlights through his work on doxa the situated nature of elite action. By considering the situated and co-constitutive characteristics of education and doxa in a particular field, it becomes possible to highlight the causes of geographically variegated elite practice.

The research I present in the rest of this chapter develops these insights by examining the role of post-first-degree (undergraduate) education in shaping the beliefs, attitudes, and working practices of earlier-career financial elites in the City of London. In other words, I seek to address in this chapter how education is used to inculcate these elites into the situated nature of legitimate socioeconomic activity in London's financial district. In so doing, I challenge assumptions that education facilitates the reproduction of a globally homogeneous elite class, entry into which has become more meritocratic because of the declining importance of educational background. Rather, I use these theoretical insights to reveal the ways in which elite financial work combines both topological and topographical components at different stages in the career life course to enhance social and spatial mobility for some while restricting it for others.

\section{Researching Early-Career Financial Elites in London's Financial District}

The analysis below is based on original empirical research conducted with earlycareer investment bankers and others professionals in London's international financial district. The research centered around 105 interviews conducted with that can be broken down into: investment bankers working in London at an early stage in their careers to discuss their postgraduate education and training experiences (53 interviews including U.K. and non-U.K. nationals); human resource managers in investment banks in London (6 interviews); educators and managers of for-profit financial business education firms in London (10 interviews); and lecturers and managers in international business schools (36 interviews). Interviews were transcribed in full and analyzed iteratively, with theoretical frameworks used to guide the initial coding. All respondents have been made anonymous and unidentifiable in the analysis below. These interview datasets were triangulated with desk-based reviews of: investment bank and education providers' websites to gather information about the wider educational landscapes available for early-career investment bankers; business and specialist new providers to document recent developments in postgraduate education and training in elite financial labor markets; policy 
documents from U.K. government departments, particularly the Department for Innovation, Universities, and Skills (DIUS), the Department for Business, Innovation and Skills, and Her Majesty's (HM) Treasury; and organizations working to support graduate employability in the United Kingdom, particularly the Higher Education Funding Council for England (HEFCE).

\section{Education and the Process of Learning the Legitimate Socioeconomic Practice of a City Financial Elite}

As I have documented elsewhere (Hall \& Appleyard, 2009, 2011), ongoing postgraduate education for early-career financial elites can be divided into three broad types, each of which is aimed at inculcating financiers into a particular set of legitimated knowledge's that are deemed important in order to work within investment banking in the City of London. First, education plays an important role in circulating and legitimating the technical know-how or "calculative devices" (Callon \& Muniesa, 2005) important within the increasingly technical nature of contemporary investment banking in the City. A second form of education focuses on the "psyknowledges" (Rose, 1998) deemed important within such labor markets and include topics such as leadership, while the third form of education concentrates on ensuring that early-career investment bankers meet the regulatory clearances required to offer investment advice in the United Kingdom. At one level, these types of postgraduate educational experience for early-career investment bankers support unquestioned assumptions about education's role in inculcating individuals into the dominant global discourses that surround financial services (on which see Clark, 2011), particularly into its technical and quantitative nature, which has intensified since the rise of securitization in the 2000s. As one interviewee noted in talking about a graduate training scheme undertaken with the other graduate recruits at the employing investment bank:

At the beginning stage, it's the technical experience, the grounding that we do...it is very broad; it's quite theoretical as well. You don't get the experience of actually applying it.

(Analyst, investment bank, London, June 2008)

This reflects changes to the investment banking business model associated with the rise of securitization and structured finance. The new approach shifted the emphasis away from the areas of mergers and acquisitions and consulting that until then had dominated investment banking in the City (see Augar, 2009), with the increasingly valued technical know-how and modeling skills supplanting the client services and client interactions previously so important in an era of "gentlemanly capitalism." However, within this education into the language of global finance (Clark, 2011) here was widespread recognition that education was much more important than simply facilitating the learning of the key tenets of quantitative finance. Rather-building here on my earlier discussion on education's role in reproducing legitimate forms of socioeconomic practice-it was widely acknowl- 
edged to be an important set of activities inculcating new-graduate hires into the meanings, cultures, and beliefs that legitimate certain forms of technical know-how. Indeed, one interviewee put it very strongly, arguing that the technical know-how of quantitative finance in isolation was "irrelevant to your career" (Investment bank analyst, City of London, London, June 2008). This suggests that postgraduate education plays an important role in allowing new early-career elites to learn the cultural meanings surrounding the implementation of technical know-how in ways deemed legitimate and appropriate by colleagues, clients, and rival banks within the City of London. As the following interview summarized:

\footnotetext{
You obviously need the theoretical background but something I've always experienced is that you have a theoretical background in something so principled, you then have the technical professional [knowledge] in a particular issue but it is almost impossible to remember that without the practical application as well. So I think they need to be very closely aligned and you can't really have one without the other-things that are really important in the workplace like presentation skills, soft skills, knowing how to approach a client and how to address them. (Investment bank president, London, September 2006)
}

Two elements of the way in which postgraduate education inculcates elites into the legitimated form of socioeconomic practice in the City are particularly important in this respect. First, education is essential in reproducing the discourse of client service that is a longstanding component of City-specific legitimate socioeconomic activity. This form of embodied know-how resonates in some ways with the emphasis on client service important in discourses of "gentlemanly capitalism" (see Anderson-Gough, Grey, \& Robson, 2000; Clark \& O’Connor, 1997; Thrift, 1994). Evidence of this was frequently commented on, with the following example being indicative:

I think in general, one of the biggest skill sets that's required is client facing skills. Just the ability to communicate clearly and concisely (Investment bank vice president, London, October 2006).

While socialization into client service is partially achieved through observing more senior colleagues, postgraduate education also plays an important part, with education providers devising innovative teaching techniques to facilitate this form of learning, often also including elements of observation. Of particular importance in this respect is the use of simulations, in which client-facing situations are enacted in the classroom using actors and finance firm senior employees. Education providers seek to offer participants opportunities to learn about the meanings and competencies associated with commercially sensitive client advice through a combination of observation (of both actors and more senior colleagues) and feedback provided after the simulation by the educators themselves and senior colleagues.

Postgraduate education is also important because it informs new recruits about legitimated meanings and competencies associated with City practice by inculcating them into specific organizational and corporate cultures referred to by Erica Schoenberger (1997) as the "social conventions" within firms. These include informal know-how about acceptable workplace behavior and shared interpretations of the regulatory norms of London's financial district The importance of this aspect of 
education illustrates that despite the firms' broadly similar knowledge bases they seek as competitors to differentiate themselves by emphasizing how their ability to deliver what would be considered appropriate advice is influenced by strengths associated with particular, firm-specific cultures of practice. In financial firms, compulsory courses for all new recruits are run in-house on a regular basis, sometimes by senior staff and sometimes by for-profit education firms. This type of education is concerned with socializing individuals into the organizationally acceptable ways of using the standard technologies or "calculative devices" (Callon \& Muniesa, 2005) underpinning most investment bank transactions. Here competency relates to knowledge about firm-specific parameters for the particular risk valuation techniques to be used (see Hall, 2008).

Such technology-specific education is supported by the wider socialization objectives of investment banks' induction programs targeting new-graduate recruits with the goal of informing individuals about how to fulfill the expectations of both the City field and the firm's senior professionals in terms of everyday practice. The approach is described by the following interviewee:

There is also quite a lot of time dedicated to them instilling and communicating the values of the company and what is going to be expected of people and giving guidance on the key values, what it means to be professional, what the standards are, and what you are expected to project on a day to day basis, so yes, quite a lot of time is spent on that in the beginning.

I think people expect that. (Investment bank vice-president, London, 2010)

Taken together, these elements reveal how postgraduate education is crucial in inculcating new recruits in investment banks into the legitimated and expected forms of socioeconomic practice within these elite labor markets. In so doing, postgraduate education moves considerably beyond simply circulating and facilitating the reproduction of technical know-how within wholesale financial workplaces in London's financial district, to include a range of embodied and sociocultural forms of knowledge.

\section{Societally and Territorially Embedding Early-Career Financial Elites Through Education}

The analysis so far has revealed the central role of postgraduate education in providing new recruits with an understanding of the legitimate meanings, competencies, and technologies (and their use) associated with City practice. At first glance, this analysis might be read as a story about the role of education in helping reproduce elites using practices attuned to the globally dominant discourses that shape the financial services sector (on which see Clark, 2011). However, although the kinds of education experienced by early-career elites in the City allows some such attuning to global investment banking labor markets, education also acts in important ways to situate City elites in a London-specific mode of practice. These educational activities suggest that in addition to facilitating entry into the topological networks 
characteristic of financial elites and elites more generally in a process well documented in the literature, postgraduate education also serves to societally and territorially embed financiers, temporally at least, in particular national and city-specific international financial districts. This involvement demonstrates how the topological and topographical are entwined within financial elite labor markets, as well as the role of education within this. In the following, I draw attention to two ways in which postgraduate education serves to embed early-career financial elites into the U.K. national economy and the City-specific international financial district in London in particular: first, briefly, by examining the role of education in inculcating elites into the regulatory frameworks of London and the United Kingdom; and second, by examining the intersection of what remain predominately national education systems with the more transnational qualities of elite financial labor markets.

Beginning with geographically specific financial services regulatory frameworks, postgraduate education gained importance because it provided individuals the opportunity to study for the credentials needed to practice as a financier and to offer investment advice in the City. At the time this chapter's research was undertaken, this meant being registered with the Financial Services Authority (FSA) in the United Kingdom, as the following interviewee summarized (for a fuller discussion of this element of postgraduate education geographies see Hall \& Appleyard, 2009):

The FSA exams basically mean I can work in the United Kingdom-if I work overseas then I'd have to go through a similar process-it's not necessarily a huge problem but it does mean for the moment I'm really a British banker and there would be some delay in terms of me generating revenue if I move to Dubai. (Investment bank vice president, London, 2010)

Beyond this regulatory element, the second way elite education served to embed financiers into particular forms of practice and associated career pathways was through its relationship to the broader national education landscape in the United Kingdom. In this respect, although financial labor markets are often assumed to be global in scope, a significant proportion of new recruits to the City come from the United Kingdom. These individuals typically hold undergraduate degrees from either Oxbridge or the Russell Group, a collection of 24 of the most researchintensive and selective universities in the United Kingdom. This fact poses important questions about how a predominately national education system intersects with the more global nature of elite financial labor markets and what the implications of this are for early-career financial elites working in investment banking in London's financial district. As Brown and Hesketh (2004, p. 23) argue in regard to graduate labor markets more generally:

Some occupational elites operate in a global rather than a local context, but they accumulate elite credentials and other cultural assets within national and local contexts. How domestic competitions are organized continue to be important to understanding the fates of the eventual winners and losers.

In the case of finance, one of the most distinctive features of the U.K. university system impacting how early-career elites enter financial labor markets are the numeracy skills required by the increasingly technical nature of investment banking 
work. While earlier generations of investment bankers in the City held degrees in a diverse range of disciplines, throughout the 2000s the recruitment strategies of investment banks favored the hiring of individuals holding undergraduate-and increasingly master's and Ph.D_-degrees in numerate subjects, notably mathematics and physics (Hall \& Appleyard, 2009; Wilmott, 2000). This preference was driven by a growing need for numerate graduates to undertake the financial modeling and analysis underpinning the securitized financial products dominating the investment banking business model in the 2000s (see also Ho, 2009 on the case of Wall Street, New York). However, investment banks have become increasingly concerned about the skills of U.K. educated graduates and their ability to meet the operational needs of investment banks, reflecting wider concerns surrounding the skill sets and employability of U.K. graduates, particularly in science, technology, engineering, and medicine (STEM subjects, on which see CBI, 2011; DIUS, 2009). As the following interviewee summarized:

I guess very generally there has been actually a problem with British students coming into banking. We find that they are just not coming through the interview process or screening process and I think that's probably true across the board of most banks. (Human resources director, investment bank, London, September 2006)

As a result, in an effort to enhance students' positional advantage within increasingly competitive financial labor markets, postgraduate education for U.K. graduates entering finance increasingly concentrates on sharpening those numerical skills that employers feel undergraduate education has left underdeveloped, The nature of postgraduate education for investment bankers has become tailored to reflect both the wider educational landscape of the United Kingdom in which it is situated and the labor market demands made of domestic and international new recruits into investment banking, as this example shows:

\footnotetext{
Because we can't always get the technical skills we want domestically, increasingly we hire international graduates on that basis but then recognize that we might need to invest a little more in their soft skills and their expectations about working in the City. That's not to say we only hire internationally, not at all, but we know that the needs of analysts tends to be different depending on where they studied for their first degree, so, we'll work with talented U.K. hires to develop their technical skills, using specialist courses and that kind of thing. (Human resources director, investment bank, London, 2009)
}

In conjunction with education aimed at meeting the regulatory clearances needed to practice as a financier, postgraduate education thus serves as an important set of activities not only by facilitating the mobility of individuals into elite financial labor markets but also by serving to- - temporarily at least-limit their mobility and territorially and to embed them societally in the legitimate forms of socioeconomic practice associated with the international financial center where they work (London's financial district in the case of this chapter). Indeed, interviewees' frequently commented on the ways in which they had to use training and orientation sessions to learn about working in other financial districts in order to overcome some of this geographical stickiness, as the following example demonstrates: 
After my initial training in New York, I was then sent on, I think, six rotations where I was working for a short period in different functions globally. It was all about learning through doing, getting a feel for the working culture, the hours, the dress, how you handle clients and of course colleagues. But that wasn't just in London even though that is where I work now. (Investment bank vice president, London, 2009)

Taken together, this suggests that postgraduate education plays an important role in inculcating early-career financial elites into the topological networks and the more topographical requirements of working in London's international financial district. Indeed, these multiple spatitialities have become increasingly marked as elite financial labor markets demand ever more quantitative skills from graduates, something that has not been a historic strength of the U.K. education system producing many of the early-career elites.

\section{Conclusions}

This chapter has taken the growing interest in economic elites as its starting point to examine the comparatively neglected role of postgraduate education in facilitating entry into and upward mobility within elite financial labor markets in London's international financial district, particularly in its investment banks. Much of the attention to date has emphasized the role of educational background at a small number of elite, fee-paying public schools and universities in the graduate recruitment process and the importance of the shared educational experience in the development of trust-based relationships between bankers and their historic regulator, the Bank of England, in the City of London (see Pryke, 1991). The research presented in this chapter builds on these insights to sharpen the focus on the significance of ongoing education beyond the first degree and second schooling in shaping the nature of socioeconomic practice in the City. In this regard, I have argued that training earlycareer elites in the technical know-how required to work in investment banks in London's contemporary international financial district is only part of the function these forms of educational experiences fulfill. Rather, education within investment banks through graduate training schemes and that provided by specialist business education providers plays an important role in inculcating new investment bank employees into the expected and legitimated practices, meanings, competencies, and cultures associated with working in investment banking in the City of London.

The wider significance of this chapter is twofold. First, theoretically, the analysis reveals the value of extending work on the sociology of education beyond the existing focus on the multiple forms of capital reproduced through educational background to include questions raised by Bourdieu's wider concepts of field, habitus, and doxa. By examining what these concepts reveal about practice, this chapter has begun to develop a valuable approach for considering how education within elite occupations not only plays an important role for individuals in securing entry into labor markets, but also serves to (re)produce understandings of legitimated forms of practice. In particular, and in relation to the focus of this book more generally, such 
an understanding is important because it challenges assumptions that investment bankers are a globally mobile, homogeneous financial class. Rather, education plays an important role in embedding (see Hess, 2004) them societally and territorially in the distinctive cultures of particular financial centers at different points in their careers. This finding reinforces recent arguments in economic geography that the topological nature of financial networks cannot be separated from the topographical dimensions of socioeconomic practice (see Pike \& Pollard, 2010).

Second, empirically, by focusing on the educational experiences of early-career elites, the analysis here has revealed the need for work on corporate and industry cultures and practices to study more carefully on the role of postgraduate educational spaces in the (re)production of situated practices. This is important because the cultures of practice within elite work have been the subject of considerable media and popular debate concerning their continued exclusionary tendencies and the implications of this for the possible growth trajectories of the global economy following the financial crisis (Cabinet Office, 2009; Treasury Committee, 2010). In this respect, it would appear that claims of the end of "gentlemanly capitalism" has heralded a more meritocratic City where upward career progression is equally available to all recruits provided they invest appropriately in their human capital through further postgraduate education and training have been exaggerated. Rather, individuals are involved in obtaining training and using it strategically to enhance their employability and positional advantage relative to other early-career elites in what remain highly competitive elite labor markets. This suggests that further postgraduate education might represent an important site of intervention if political aims to alter the culture of the City and render it more meritocratic and sustainable in terms of its financial practices are to be fully realized.

Acknowledgements The research reported in this chapter was funded by the Nuffield Foundation (SGS/3204) and the Economic and Social Research Council (RES-061-25-0071).

\section{References}

Amin, A., \& Cohendet, P. (2004). Architectures of knowledge: Firms, capabilities and communities. Oxford: University Press.

Anderson-Gough, F., Grey, C., \& Robson, K. (2000). In the name of the client: The service ethic in two professional services firms. Human Relations, 53, 1151-1174. doi: $10.1177 / 0018726700539003$

Augar, P. (2001). The death of gentlemanly capitalism: The rise and fall of London's investment banks (2nd ed.). London: Penguin.

Augar, P. (2009). Chasing Alpha: How reckless growth and unchecked ambition ruined the City's golden decade. London: Bodley Head.

Becker, G. (1994). Human capital: Theoretical and empirical analysis with special reference to education. Chicago: University of Chicago Press.

Bourdieu, P. (1990). The logic of practice (R. Nice, Trans.). Stanford: University Press. (Original work published 1980)

Bourdieu, P. (1996). The state nobility: Elite schools in the field of power (L. C. Clough, Trans.). Stanford: University Press. (Original work published 1989) 
Brown, P. (2000). The globalisation of positional competition? Sociology, 34, 633-653. doi:10.1177/S0038038500000390

Brown, P., \& Hesketh, A. (2004). The mismanagement of talent: Employability and jobs in the knowledge economy. Oxford: University Press.

Cabinet Office, (2009). Unleashing aspiration: The final report on fair access to the professions (Ref:296833/07 09). Retrieved from http://webarchive.nationalarchives.gov.uk/+/http:/www. cabinetoffice.gov.uk/media/227102/fair-access.pdf

Callon, M., \& Muniesa, F. (2005). Peripheral vision: Economic markets as calculative collective devices, Organization Studies, 26, 1229-1250. doi:10.1177/0170840605056393

Castells, M. (1996). The information age: Economy, society and culture: Vol. 1. The rise of the network society. Oxford: Blackwell.

CBI (2011). Building for growth: Business priorities for education and skills. London, UK: CBI. Retrieved from http://www.cbi.org.uk/media/1051530/cbi_edi_education__skills_survey_2011.pdf

Clark, G. L. (2011). Myopia and the global financial crisis. Dialogues in Human Geography, 1, 4-25. doi:10.1177/2043820610386318

Clark, G. L., \& O'Connor, K. (1997). The informational content of financial products and the spatial structure of the global finance industry. In K. Cox (Ed.), Spaces of Globalization: Reasserting the power of the local (pp. 89-114). New York: Guildford Press.

Daloz, J.-P. (2010). The sociology of elite distinction. From theoretical to comparative perspectives. Basingstoke: Palgrave Macmillan.

Department for Education and Skills (DIUS), (2009). The demand for science, technology, engineering and mathematics skills. London: Crown Copyright.

Engelen, E., Konings, M., \& Fernandez, R. (2010). Geographies of financialization in disarray: The Dutch case in comparative perspective. Economic Geography, 86, 53-73. doi:10.1111/j.1944-8287.2009.01054.x

Faulconbridge, J. R., \& Hall, S. (2014). Reproducing the city of London's institutional landscape: The role of education and the learning of situated practices by early-career elites. Environment and Planning A, 46, 1682-1696. doi:10.1068/a45392

Folkman, P., Froud, J., Johal, S., \& Williams, K. (2007). Working for themselves? Capital market intermediaries and present day capitalism. Business History, 49, 552-572. doi: $10.1080 / 00076790701296373$

Froud, J., Johal, S., Leaver, A., \& Williams, K. (2006). Financialization and strategy. Narrative and numbers. London: Routledge.

Hall, S. (2008). Geographies of business education: MBA programmes, reflexive business schools and the cultural circuit of capital. Transactions of the Institute of British Geographers, 33, 27-41. doi:10.1111/j.1475-5661.2007.00288.x

Hall, S., \& Appleyard, L. (2009). City of London, city of learning? Placing business education within the geographies of finance. Journal of Economic Geography, 9, 597-617. doi:10.1093/ jeg/lbp026

Hall, S., \& Appleyard, L. (2011). Trans-local academic credentials and the (re)production of financial elites. Globalisation, Societies and Education, 9, 247-564. doi:10.1080/14767724.2011.5 77177

Hess, M. (2004). Spatial relationships? Towards a reconceptualization of embeddedness. Progress in Human Geography, 28, 165-186. doi:10.1191/0309132504ph479oa

Ho, K. (2009). Liquidated: An ethnography of Wall Street. Durham: Duke University Press.

Kynaston, D. (2002). The City of London: Vol. 4. Club no more, 1945-2000. London: Pimlico.

Leyshon, A., \& Thrift, N. (1997). Money/Space: Geographies of monetary transformations. London: Routledge.

McDowell, L. (1997). Capital culture: Gender at work in the City of London. Oxford: Blackwell.

Pike, A., \& Pollard, J. (2010). Economic geographies of financialization. Economic Geography, 86, 29-51. doi:10.1111/j.1944-8287.2009.01057.x

Pryke, M. (1991). An international city going global: Spatial change in the City of London. Environment and Planning D: Society and Space, 9, 197-222. doi:10.1068/d090197 
Rose, N. (1998). Inventing our selves: Psychology, power and person hood. Cambridge, UK: University Press.

Savage, M., \& Williams, K. (2008). Elites: Remembered in capitalism and forgotten by social sciences. In M. Savage \& K. Williams (Eds.), Remembering elites (pp. 1-24). Oxford: Blackwell.

Schoenberger, E. (1997). The cultural crisis of the firm. Oxford: Blackwell.

Sklair, L. (2001). The transnational capitalist class. Oxford: Blackwell.

Tett, G. (2009). Fool's gold: The inside story of J.P. Morgan and how Wall St. greed corrupted its bold dream and created a financial catastrophe. New York: Free Press.

Thrift, N. (1994). On the social and cultural determinants of international financial centres: The case of the City of London. In S. Corbridge (Ed.), Money, power and space (pp. 327-355). Oxford: Blackwell.

Tickell, A. (1996). Making a melodrama out of a crisis: Reinterpreting the collapse of Barings Bank. Environment and Planning D: Society and Space, 14, 5-33. doi:10.1068/d140005

Treasury Committee (2010). Women in the City. Tenth report of session 2009-10. London, UK: House of Commons. Retrieved from http://www.publications.parliament.uk/pa/cm200910/ cmselect/cmtreasy/482/482.pdf

Waters, J. L. (2007). Roundabout routes and sanctuary schools: The role of situated educational practices and habitus in the creation of transnational professionals. Global Networks, 7, 477497. doi:10.1111/j.1471-0374.2007.00180.x

Waters, J. L. (2009). In pursuit of scarcity: Transnational students, employability and the MBA. Environment and Planning A, 41, 1865-1883. doi:10.1068/a40319

Wenger, E. (1998). Communities of practice: Learning meaning and identity. Cambridge, UK: Cambridge University Press.

Wilmott, P. (2000). The use, misuse and abuse of mathematics in finance. Philosophical Transactions of the Royal Society A, 358, 63-73. doi:10.1098/rsta.2000.0519

Wójcik, D. (2011). Securitization and its footprint: The rise of the US securities industry centers 1998-2007, Journal of Economic Geography, 11, 925-947. doi:10.1093/jeg/lbq045

Open Access This chapter is distributed under the terms of the Creative Commons Attribution 4.0 International License (http://creativecommons.org/licenses/by/4.0/), which permits use, duplication, adaptation, distribution and reproduction in any medium or format, as long as you give appropriate credit to the original author(s) and the source, provide a link to the Creative Commons license and indicate if changes were made.

The images or other third party material in this chapter are included in the work's Creative Commons license, unless indicated otherwise in the credit line; if such material is not included in the work's Creative Commons license and the respective action is not permitted by statutory regulation, users will need to obtain permission from the license holder to duplicate, adapt or reproduce the material. 